\title{
Introduction
}

India has retained its character of a peasant society despite the accelerated process of urbanization and industrialization which it has undergone in the last few decades. As the census of 1961 showed, 82 percent of the population lives in rural areas, and roughly 70 percent is engaged in agriculture. These figures in themselves more than justify the continued interest of sociologists and anthropologists in India's rural structure.

Nevertheless, until recently only a limited part of the abundant literature on village India was concerned with agrarian sociology. A major preoccupation has been to study the caste society as a clearcut system of social organization, while the network of social relationships involved in the organization of agrarian production has long remained of secondary interest.

Although it was generally recognized that India is not one of those peasant societies with little differentiation as to ownership and utilization of land on the village level, information on the division of the local community into landowners, small farmers, and agricultural laborers often had to give way before detailed description of the variations among the artisan and serving castes. What surprises us is that, in the sometimes very detailed listings of the activities of the various castes, agricultural labor - surely the principal activity in a peasant economy - is scarcely mentioned, except as work which is not very specific and can be performed by members of all castes.

Moreover, in many publications based on field work the propertied high castes in a village received proportionately more attention than the others. Concerning the members of the lower castes, often landless, data are much more scanty. As a result, we know comparatively little about the conditions in which the poorest people in India work and earn a living. They are the agricultural laborers, who are estimated to constitute approximately 25 percent of the agrarian population. It is true that two successive government reports - the records of the Agricultural Labour Enquiry of 195051 and 1956-57 - have made available a great deal of information in regard to this category, but the material they contain has not been interpreted in a wider framework. 
My study is concerned with landowners and agricultural laborers in the southern part of the State of Gujarat. It is based on a combination of source studies and field-work reports. The relations between Anavil Brahmans, the principal local landowners, and Dublas, a tribal caste of landless laborers, still contain many elements of the form of service which existed in earlier times and which is generally known as the hali system.

For an understanding of the present situation an insight into the position of the agricultural laborer in the past is indeed of essential importance. After my field-work period, this conclusion led me to a study of the historical sources, which would enable me to analyze the master-servant relationship in the traditional society. Thus, the results of my investigation into the existing situation formed for me the starting-point for an interpretation of the past relationships between the two groups, and not the other way round. This made my book difficult to plan, but in the end I decided to arrange the chapters in chronological order, so that the material leads from the general to the particular. By employing data that go back to the beginning of the nineteenth century I have tried to record and explain the successive changes in the relationships between landowners and landless laborers, two important categories in the rural structure.

In order to place my argument against a more general background, I have begun this study with a brief outline of the development of agrarian labor relationships in India. This introduces a theoretical discussion of the relationships between landowners and agricultural laborers in the light of the jajmani system, the framework in which the intercaste relationships in the traditional society were institutionalized (part I). A brief description of the country and people of south Gujarat is then followed by a summary of the hali system as it functioned during the last century in the region under discussion, and of the changes which have occurred since then (part II). The conclusions from this part of my account are at the same time a starting-point for the report of the investigation into the existing relationships between landowners and agricultural laborers which I carried out in two south Gujarat villages during 1962 and 1963 (part III).

While my aim during field work was to gather data on the present situation, I supplemented my study by examining historical material after my return from India. A subsidy from the Netherlands Organization for the Advancement of Pure Research in 1966 enabled me 
to consult published and unpublished documents in a number of London libraries, and the same organization made possible the present English translation by Mrs. Wil van Gulik from the original Dutch version published in 1970.

The continuous exchange of ideas with Professor Wertheim before my departure, during his visit in the field, and after my return - has clarified for me the concept of guru.

The friendly cooperation in India with Chris Baks, Enno Hommes, Igle Ronner, and Klaas van der Veen - my fellow-participants in the Gujarat project - has been of great importance to me, and a source of inspiration.

Miss H. L. Lambert, M.A., who was at the time attached to the London School of Oriental and African Studies and taught me Gujarati, made it easier for me to conduct my investigation and enabled me to be a little less of an outsider in the community with which I associated for a time.

Without wishing to understate the help of all those who assisted me in India when I was carrying out the investigation, I feel that special thanks are due to Professor I. P. Desai and Professor M. B. Desai. Their professional qualifications (sociology and agricultural economy, respectively) and their personal familiarity with the region under research, resulted in advice and suggestions that were very valuable to me. I am, moreover, indebted to Professor and Mrs. M. B. Desai for the hospitality and assistance they gave my wife during her stay in Baroda.

Professor K. de Vreese of the University of Amsterdam was so kind as to check the Glossary for imperfections. I would also like to express my appreciation to Professor Köbben for his careful reading of the manuscript. The final result bears to some extent the stamp of his many critical notes.

Finally, I gratefully acknowledge the aid I received from my wife. She corrected the final text, but, much more important, in the earlier stages of gathering and writing up materials she put me right many times.

"It is my duty . . ." In this way the Anavil Brahmans of south Gujarat deprecate expressions of gratitude, even if they wish to leave no doubt of the obligations under which their interlocutor has just come. It gives me pleasure that I am able at last to honor these obligations. Dutiful acknowledgement is, however, the last of the reasons why I have mentioned a number of people by name who 
helped me in the course of my study. Nevertheless I take this opportunity to express my most profound thanks to all those who enabled me in the field to collect the data of which this book is the result.

After an interval of seven years, I returned to south Gujarat in the summer of 1971 to carry out a new research project: an analysis of the institutional framework of unskilled labor and of the social mobilization of rural and urban laborers in the district. I used this opportunity to revisit the scenes of my earlier field work and to renew my association with the people I had known before. I was especially interested in finding out how the "green revolution" had manifested itself in the area.

In the Postscript, written after my return to the Netherlands in 1972 , I comment on continuity and change in the relations between landlords and agricultural laborers in south Gujarat.

\section{Jan Breman}

Faculty of the Social Sciences

Erasmus University

Rotterdam 